\title{
Organizational Culture, Motivation, Job Satisfaction and Performance of Employees toward the Implementation of Internal Bureaucracy Reform in the Ministry for the Empowerment of State Apparatus and Bureaucracy Reform (The Ministry of PANRB)
}

\author{
Ismiyarto $^{1}$, Sri Suwitri ${ }^{1}$, Y. Warella ${ }^{1} \&$ Sundarso $^{1}$ \\ ${ }^{1}$ Doctoral Program of Public Administration, Faculty of Social and Political Sciences, Diponegoro University, \\ Semarang, Indonesia \\ Correspondence: Sri Suwitri, Doctoral Program of Public Administration, Faculty of Social and Political \\ Sciences, Diponegoro University, Building of Postgraduate Diponegoro University; $5^{\text {th }}$ Floor, Imam Bardjo, SH \\ Street No. 3-5 Semarang, Indonesia. Tel: 62-857-2697-2565 or 62-856-4113-0512. E-mail: \\ programdap@yahoo.com
}

Received: November 13, 2014

Accepted: January 3, 2015 Online Published: February 20, 2015

doi:10.5539/jms.v5n1p192

URL: http://dx.doi.org/10.5539/jms.v5n1p192

\begin{abstract}
Implementation of bureaucratic reform agenda in a government agency is determined by the culture of the organization and human resources of the institution. This study aimed to discover how organizational cultural relations, motivation, job satisfaction, and performance of the bureaucracy reform internally perceived by the employees at the Ministry of PANRB. This study used a qualitative approach. One of the sources of data is surveys conducted by the Ministry of PANRB. The results showed that employee satisfaction on the implementation of bureaucratic reform internally at the Ministry of PANRB satisfied enough (with values 66.93), high employee motivation (with values 68.91), while employee satisfaction on the implementation of internal bureaucratic reform is high also (with values 68.51). These results can be used for the implementation of the next survey, and as research material in the field of public administration or other similar science.
\end{abstract}

Keywords: organizational culture, motivation, job satisfaction, performance, bureaucracy reform

\section{Introduction}

The nation for more than 69 years, it has not been able to realize the bureaucracy figure as expected, particularly in the public service that held the government bureaucracy. According to Siagian (1996:39) some of the problems often become public complaints related services of the government bureaucracy by apparatus usually show behaviors that "annoying" or deviant, including (1) delay the completion of the licensing process (settlement documents are not in accordance with the time defined), (2) look for excuses like as incomplete of supporting documents, delays in the submission of application and other similar pretext, (3) the reason busyness perform for other tasks, (4) difficult to contact, and (5) always slow down with use of the words being processed.

Variety of deviant behavior of bureaucrats is causing high economy cost, Indonesia is the country that has not been free from this deviant behavior. The survey results of Corruption Perceptions Index by Transparency International in 2013 showed that Indonesia was in a position at 114, ironic when compared to neighboring countries such as Thailand and Singapore which ranked 11 and 5. Based on the Efficiency of bureaucracy Scores 2012 Asian Countries, Singapore get the value of 2.25, Indonesia 8.37, while India 9.21. Various criticisms of inefficiency in the Indonesian bureaucracy system, the quantity is too large and rigid've often stated openly that a "disease" in the bureaucratic system of government in Indonesia (Thoha, 2009, p. 11). Thus bureaucracy in Indonesia has not been able to carry out the tasks of government and development effectively and efficiently.

Bureaucracy by definition put forward by some experts is a control system in an organization that is designed based on the rules of rational, systematic and aims to coordinate and direct the work activities of individuals in the context of the completion of administrative tasks large (excerpted from Blau \& Meyer, 1971; Coser \& Rosenberg, 1976; Mouzelis, in Setiawan, 1998). Meanwhile, according to Blau in the Sinambela (2006, p. 70), says that bureaucracy is an organization devoted to maximize efficiency in the administration. 
Reform is needed in the government because (1) the reform contains linkage innovation and transformation, (2) the success of the reforms require changes in the framework of a systematic and extensive, and these changes must be by way of careful and planned, (3) the purpose of the reform is to achieve efficiency and effectiveness, and (4) reform should be able to cope with changes. Thus, the scope of reform is not limited to processes and procedures, but also related to changes in the level of structure and attitude and behavior. This means that it relates to issues that intersect with the authority or power.

According to experts, there are several factors which led to the reform of the bureaucracy (Leverage Points Reform). Thoha (2009, p. 106) explains that the factors that can encourage reform of the government bureaucracy, namely (1) the need to make changes and updates, (2) understand the changes that occur in the environment of national strategic, (3) understand the changes that occur in the environment of global strategic, and (4) understand the changes that occur in government management paradigm.

There is a need to make changes and updates bureaucracy depending on the needs of the national leadership, which starts from the President to perform the update. Reform seems unlikely to be effective if it is not in the grip of government control of the nation state in this case the President. National strategic environmental changes in the bureaucracy will cause the plan and update the apparatus of state/government, a change since the 1998 economic crisis/monetary and changes in the national political system and so on are left as if bureaucratic reform.

According to Prasojo (2012, p. 10), there are at least 12 programs that could be the lever (leverege) in the acceleration of bureaucratic reforms, namely (1) assessment of the organization of ministries/agencies, (2) the toughest of recruits based on information and technology systems, (3) a system for filling the open positions (promotion), (4) monitoring system of public services, (5) public service complaints system nationally, (6) resource management system of government, (7) reform the Reformers in the Ministry of PANRB, (8) a public campaign to reform the bureaucracy, (9) competency test (talents mapping) civil servants, (10) e-integrated competence based human resource system, (11) the construction of the integrity zone to the free area of corruption, and (12) the development of self-assessment system of bureaucratic reforms (PMPRB) is online.

Meanwhile, Keban (2009, p. 251) explains that there are four aspects of why reform of the bureaucracy needs to be implemented, namely (1) building a bureaucratic vision, (2) building human bureaucracy, (3) building a bureaucratic system, and (4) building a bureaucratic environment. Furthermore, in establishing a system of bureaucratic Keban said that the improvement of organizational culture associated with the pattern of values and norms and beliefs that can help members of the organization will certainly understand how the organization should function, and how these values and beliefs guide their behavior in organizations. Organizational culture has been shown to determine the performance of the bureaucracy because it influences the behavior of bureaucrats (Marcoulides \& Heck, 1993; Dilulio, 1994 in Keban, 2008, p. 255).

Based on expert opinion with regard to some of the factors which led to the reform of the bureaucracy (Leverage Points Reform), can be described in the following table:

Table 1. The drivers factor of bureaucracy reform arising (leverage points reform)

\begin{tabular}{|c|c|c|}
\hline No. ${ }_{0 .}$ & Opinion & Leverage Points Reform \\
\hline 1. & Thoha (2009:106) & $\begin{array}{l}\text { - global strategic environment: decentralization system, democracy, autonomy, accountability, } \\
\text { transparency, and the rule of law; } \\
\text { - } \quad \text { national strategic environment: reform controlled by president; }\end{array}$ \\
\hline 2. & $\begin{array}{l}\text { Rewansyah } \\
(2009: 134)\end{array}$ & $\begin{array}{l}\text { democratic and decentralized of governance system; } \\
\text { objective conditions of the nation and the government bureaucracy; }\end{array}$ \\
\hline 3. & Prasojo (2012:10) & $\begin{array}{l}\text { - development system of human resources, organization of } \mathrm{K} / \mathrm{L} \text {, monitoring and complaint of } \\
\text { public services; } \\
\text { - } \quad \text { development system of independent evaluation of bureaucratic reforms (PMPRB) online; }\end{array}$ \\
\hline 4. & $\begin{array}{l}\text { Keban } \\
(2009: 251-255)\end{array}$ & $\begin{array}{l}\text { - development of vision. human and environmental of bureaucracy; } \\
\text { - } \quad \text { bureaucracy system: structure, appropriate strategies and revamping the organization's } \\
\text { culture; } \\
\text { - } \quad \text { organizational culture proved decisive bureaucratic performance because it influences the } \\
\text { behavior of bureaucrats. }\end{array}$ \\
\hline
\end{tabular}

Source: The expert's opinion. 
The driving factor bureaucratic reforms suggested by experts that there is common ground that the development of the system of government or bureaucratic system. The difference of opinion submitted to the experts: First, Thoha namely the national strategic environment that the implementation of the national bureaucracy reform will be effective if it is controlled by the president, this is in accordance with case studies on bureaucratic reform in developing countries shows how important leadership variables consistent (Zauhar, 2012, p. 88). Second, Prasojo namely the construction of self-assessment system of bureaucratic reforms (PMPRB) online, this assessment model based on the principles of Total Quality Management (TQM) and is used as a method to conduct a thorough assessment and analysis of the performance of government agencies, not only seeing the side process but also the results and feedback obtained from the implementation of bureaucratic reform. Thus each ministry/agency/government can carry out the stages of bureaucratic reform independently (self-assessment) is set in the Ministerial Regulation of PANRB No. 31 year 2012. Third, Keban opinion is one of the driving factors of bureaucratic reform at the top, especially in the bureaucratic system that is the revamping organizational culture that determines the performance of the bureaucracy because it influences the behavior of bureaucrats or government officials (which is the subject of this writing). Improve the organizational culture with one of the most severe behavioral dimensions in the implementation of the reform of the bureaucracy when compared to improvements in processes, structures and procedures (TS. Ambar and Setiyono, 2011, p. 34).

In the framework of the implementation of bureaucratic reforms, the Government has issued Presidential Regulation No. 81 Year 2010 Grand Design Bureaucratic Reforms 2010-2025 has great significance, because of: First, become an instrument that connects the direction of bureaucratic reform policy as expressed in the RPJP 2005 to 2025. The main operational-step for the medium-term plan period (RPJM); Second, to be a basic framework in preparing the detailed steps (roadmap) reform of the bureaucracy over the five-year nationally; Third, being a basic framework for the Ministry/Institution/Local Government in preparing his bureaucratic reform roadmap institution.

Grand Design of Bureaucracy Reforms becomes a reference for the Ministry/Institution/Local Government to reform the bureaucracy in order to realize good governance. Operational implementation will be set forth in the Road Map of Bureaucracy Reforms determined every five years by the Minister of PANRB.

Based on Presidential Regulation Number 81 Year 2010 about the Grand Design Bureaucratic Reforms 2010-2025, the strategy of bureaucratic reforms to implement the 8 (eight) areas of change, followed by the Road Map Bureaucratic Reforms established by the Minister of PANRB No. 20 Year 2010 aims to provide the direction of bureaucratic reforms in the Ministries/Agencies and Local Government in order to run an effectively, efficiently, scalable, consistent, integrated, institutionalized, and sustainable.

Performance governmental organizations is not optimal, it's affected by a factor that is organizational culture, it is appropriate Yuwono opinion, et al $(2002$, p. 53) argues that the dominant factors affecting the performance of the organization include of: management's efforts to translate and align organizational goals, organizational culture, quality of human resources owned by the effective organization and leadership. The next opinion delivered Atmosoeprapto in Tangkilsan (2007, p. 181) in the organization's internal factors that affect the performance of the organization include of: organizational culture, which is the style and identity of an organization in a standard work patterns and the image of the organization concerned.

The next opinion said that performance of government organizations has not been optimal (Sembiring, 2012, p. 121 ) is affected by a factor that is not yet strong organizational culture among public organizations in addition to other factors. The next opinions Sembiring said strong organizational culture will influence the motivation and behavior of all members of the organization to produce the performance of the organization. Values and attitudes of togetherness must be transmitted by the leadership to all members of the organization and also the leadership is expected to be an example of good (not enough just to transmit the values with the organization).

Organizational culture, motivation, job satisfaction and performance are the object of research that attracted the attention of many researchers. It also seized the attention of $\mathrm{H}$. Teman Koesmono - http: puslit.petra.ac.id/-pusliti/journals/ - which examines the influence of organizational culture on motivation and job satisfaction and performance, where the results of his research concludes that organizational culture can affect motivation and job satisfaction and performance (Koesmono, 2005, p. 176). His research a continuing research study conducted by Herpen et al. (2002) it's found that the factors of organizational behavior: Organizational Culture, Motivation and Job Satisfaction indeed have an influence on performance.

In line with other authors Widodo (2011) with title: "The Influence of Organizational Culture and Work Motivation on Teacher Performance" with the conclusion that organizational culture has an influence on the 
performance, motivation to have an influence on performance, and jointly organizational culture and work motivation has influence on the performance.

As described above in this writing there are variables of organizational culture, bureaucratic reform, submitted the following variables associated with this paper is motivation, job satisfaction and performance.

Motivation is something that moves people to act in a certain way. Motivation is different between individuals with each other, so that it's causing a difference in behavior between individuals. Included in the motivation is the need, desire, tension, unhappiness and hope. This motivation can be triggered by various stimuli both from within and from outside the individual. The leader tried to have a team with high performance needed to motivate members to work to achieve organizational goals, reduce idleness, and helped his team to resolve conflicts objectively (Jones \& George, 2008, pp. 519 \& 617). Employee motivation will be pushed if insufficient salary / income, and economic benefits to the needs of the family. The existence of employee facilities is such as health insurance, retirement benefits. Workplace conditions are calm and comfortable working environment. Attitude of employee's behavior embodied friends working together in carrying out the work is always in groups and communicates well. No less important attitude of the leadership and achievement awards for the work that has been accomplished.

Job satisfaction, satisfaction is a feeling that is experienced and perceived by someone, what is expected to have been met or even received more than expected, while the one's work is an attempt to achieve the goal by obtaining income or compensation of its contribution to the work place. Job satisfaction will be achieved when the input current direction and policy formulation in an acceptable organization; Employees feel the activities undertaken by the organization can be perceived benefits; The consistent leadership in driving the implementation of activities within the organization.

Generally more positive attitude towards work, the greater the job satisfaction, for the various indicators of job satisfaction need special attention so that workers can improve its performance. In general, a person is satisfied with his work as successfully and obtains a fair assessment of its leaders (Koesmono, 2005, p. 170).

Performance is defined as the result of the quality and quantity of work that can be accomplished by someone employees in carrying out duties in accordance with the responsibilities assigned to him (Mangkunagara, 2001, p. 67). Another view of performance is the output generated by functions or indicators of a job or a profession in a certain time (Wirawan, 2009, p. 5). Criteria or indicators used to measure the performance of the bureaucracy of how beneficial the resulting policy bureaucrats to the welfare of society; The extent to which policies will be issued involving community participation, whether the policy is beneficial to society or to the detriment of society.

One public organization that regulates national bureaucratic reform is the Ministry PANRB, but it also plays a role in formulating policies and operational strategies of bureaucratic reform and monitor and evaluate the implementation of bureaucratic reforms at the national level which includes the entire Ministry / Agency / Local Government. This paper highlights the organizational culture, motivation, job satisfaction and employee performance against internal scope of bureaucratic reforms at the Ministry PANRB.

\section{Methods}

This study used a qualitative research approach. The data collected is secondary, then analyzed and resulting interpretation. Secondary data which is collected and analyzed are the results of a survey conducted by the Ministry PANRB, journals and literature review of relevant studies, and related policy documents. This research uses qualitative data analysis, which includes an important component of data reduction, data presentation and conclusion. This study chose Ministry PANRB as a test site in order to analyze the implementation of the bureaucracy reform in the internal sphere in the period of 2011 to 2013.

\section{Results and Discussion}

In the results and discussion, it's described the culture of the organization, motivation, job satisfaction, and employee performance in the implementation of internal bureaucratic reform in the Ministry PANRB. This study took the organizational culture, motivation, job satisfaction, and motivation of employees based on the results manifest the theory proposed by Koesmono (2005) and Widodo (2011). Operationally the four variables can be defined that are (1) motivation is the force or impulse that causes the employee to behave in a certain way, (2) job satisfaction is the level of individual feeling positively or negatively in the aspects of his work, (3) the performance of an employee performance in performing their duties, and (4) defined organizational culture as norms, values, beliefs, customs organizations that affect the mindset, attitudes and patterns of behavior of 
members of the organization in achieving organizational goals. If all four are connected will be seen in the following figure.

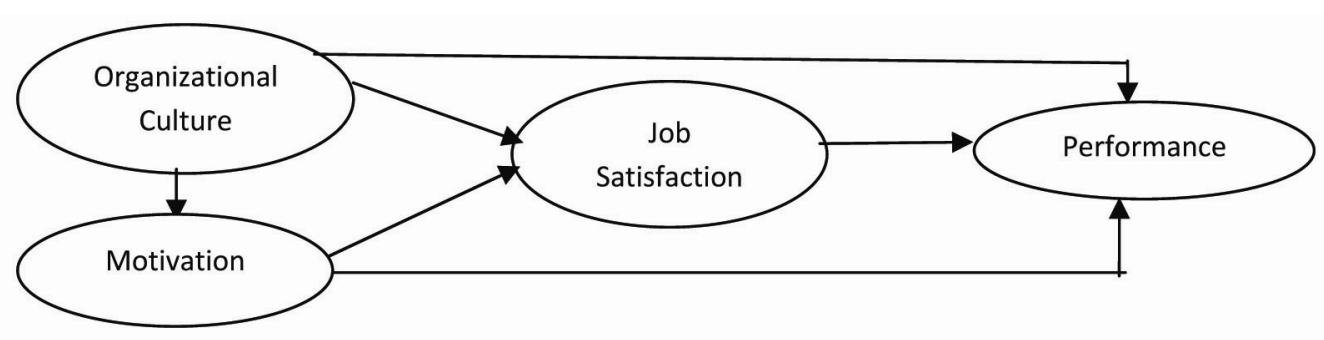

Figure 1. Relation of culture organizational, motivation, job satisfaction, and performance

Source: Koesmono (2005) and Sembiring (2012).

The relationship of cultural organization with the performance of the organization as described above, it can be concluded that the dimensions of organizational culture values, attitudes shared believed the truth and excellence bind all members of the organization are motivated and encouraged to behave in order to achieve overall organizational performance. In other words, it can be argued that a strong organizational culture will affect all members of the organization to work and behave motivated in order to generate daily performance in order to achieve organizational goals that have been set as the meaning and significance of bureaucratic reform.

\subsection{Organizational Culture}

Organizational culture is one of the areas of bureaucratic reform changes. In the area of these changes, the organizational culture into one package with an agenda change in mindset. It is based on a mindset of bureaucracy, it is a rule-based. The mindset is considered a limiting factor bureaucratic reform. With this mindset, the regulations that hamper the performance of the bureaucracy not be changed. As a result, bureaucratic culture is considered not accelerate and improve the application of bureaucratic reform policy.

Partnership (2014) through by the Reform the Reformers Continuation program (RTR-C) in collaboration with the Ministry of PANRB surveyed the progress of bureaucratic reform in the Ministry PANRB. Assessment of the Ministry PANRB shows that the average index of the external perception of the respondents was 3.61. It is included in the category Good Enough. Value of the index rose 0.4 points compared with the index before 2010 were only worth 3.21. The study provides a general conclusion that objective, policies are made by the Ministry PANRB have influenced the increase in the perception of external respondents, particularly in understanding the direction of reform developed by the Ministry PANRB as the leading sector of bureaucratic reform in Indonesia. When viewed through out the lens of organizational culture, the perception of external parties indicate that there is little progress organizational culture that is created in the Ministry PANRB, so as to become the leading sector bureaucratic reform in Indonesia.

The external perception is much lower than the internal perception, the employees of the Ministry of PANRB (Minister PANRB, 2014). PANRB Minister continued that the external assessment should be used as a handle than internal assessment, because it is considered more objective. Thus, it shows that organizational culture has not been effective to support and encourage the reform of internal bureaucracy in the Ministry of PANRB.

\subsection{Work Motivation}

From the results of a survey conducted by the Ministry PANRB in 2011 to 2013, the level of work motivation shows the average employee motivation index of 3.49 (maximum value of 5) with a value of interpretation/conversion $\rightarrow 67.32$ (maximum value of 100). This means that the level of employee motivation showed results very satisfied. There was a civil servant statement is a call of the soul, and must be carried out with great devotion, while the results are not satisfied look at the statement as civil facilities such as health insurance and retirement benefits.

Employee motivation is with regard to various matters. Revenue of PNS becomes the most important indicator. Although on average the respondents are satisfied with the income received, but it is not supported by allowances and facilities (such as health insurance and retirement benefits). Besides related income, the majority 
of civil servants in the Ministry of PANRB feel motivated because the workplace, office environment, the attitude of colleagues, and the attitude of the leadership.

Indicators question of motivation, when referring to the theory, it can be concluded as the theory described by Luthans (2006). Luthans motivation is divided into two variables, namely motivational and hygiene. Motivational Motivation are things that are intrinsic drivers of achievement that comes from within oneself. Belonging to the motivational factor is a person's job, the success achieved, the opportunity to grow, progress in career and recognition of others. Hygiene motivation and maintenance are factors that are extrinsic sourced from outside oneself. They were classified as hygiene or maintenance factors, among others, the status of a person in the organization, relations between employee and superiors, relationships with colleagues, wisdom organizational, administrative systems within the organization, working conditions and remuneration systems applicable. Assessment conformity with the theory put forward by Luthans (2008) can be seen in Table 2 .

Table 2 Assessment of employee work motivation

\begin{tabular}{|c|c|c|c|}
\hline \multirow{6}{*}{ Concept } & Variable & Indicator & Assessment \\
\hline & & Job & Satisfied \\
\hline & & The success achieved & Satisfied \\
\hline & Motivational & Opportunity for developing & Satisfied \\
\hline & & Progress in career Satisfied & Satisfied \\
\hline & & Recognition of others & Satisfied \\
\hline \multirow[t]{7}{*}{ Motivation } & & Hygiene status of employees in the organization & Satisfied \\
\hline & & Employee relationship with the boss & Satisfied \\
\hline & & Relationships with colleagues & Satisfied \\
\hline & Hygiene & Organization Wisdom & Satisfied \\
\hline & & Administrative systems within the organization & Satisfied \\
\hline & & Working conditions & Satisfied \\
\hline & & The reward system which applies & Enough \\
\hline
\end{tabular}

Source: Luthans, 2008 and Survey Ministry PANRB, 2013.

\subsection{Employee Satisfaction}

The results of Ministry of PANRB survey in 2011 to 2013 related to the level of employee satisfaction shows that the average employee satisfaction index of 3.76 (maximum value of 5) with a value of interpretation/conversion 62.59 (maximum value of 100). The level of employee satisfaction on the organization showing the results are very satisfied with the leadership coaching to staff, while the results are not satisfied for benefits statement with the amount of responsibility given.

In this aspect of job satisfaction, the majority of employees are satisfied with his position now. Employee satisfaction in the occupied position is influenced by factors of due tasks that employees with the interests and talents. Thus, employees have the satisfaction of the results of the tasks are done.

Employees of the Ministry of PANRB expressed satisfaction level in career development through a variety of responses. Not all employees are satisfied with the implementation of the promotion policy and personnel transfers. In other words, there is a sense less satisfied with the assurance in career development. If referring to expert opinion as Edy (2008) explains that there are problems in the bureaucratic system of career development in Indonesia. Those problems are still many career developments on the basis of kinship, closeness, friendship, and personal interests (Edy, 2008).

Employee satisfaction is also seen from the work environment indicators. The majority of employees of the Ministry PANRB are satisfied with the environment that have co-workers who can work together, the guarantee of security in carrying out the work, even to the extent of satisfaction has kinship with friends work together. In addition, employees of the Ministry PANRB satisfied with the availability of facilities and infrastructure to support the execution of the work.

\subsection{Employee Performance}

Employee performance is a key factor of the success of the organization. Therefore, high or low performance of employees of the Ministry of PANRB will affect the performance of the Ministry of PANRB as an organization. In 2013, the level of achievement the Ministry of PANRB of $80 \%$ by calculation that the target of 26 
performance indicators, as many as 21 indicators categorized "Good" and as much as 5 indicators has not been achieved.

In the context of the implementation of internal bureaucratic reform, employees of the Ministry PANRB at least have demonstrated participation. The level of participation and employee satisfaction on the implementation of internal bureaucratic reform in the Ministry of PANRB survey during three times for three consecutive years with an average yield of 4.12 index of employee motivation (maximum value 5) with a value of interpretation/conversion 67.73 (maximum value of 100). The level of participation and employee satisfaction on the implementation of bureaucratic reform in the internal sphere The Ministry of PANRB show results very satisfied. The results indicated that one of the activities carried out Internal Team of Bureaucracy Reforms, such as the Reform Corner, Agents of Change, Integrity Group, and others known to all employees. However, there is a statement that shows the negative side as resistance to encourage the implementation of bureaucratic reform.

Based on the results of questionnaires conducted in 2013, a few things that need attention that can support the employee's performance, namely, first, human resources issues, among others, (1) the need for clarity of career paths and talent mapping as one of the basic considerations, (2) increase in awards to employees in terms of performance, the selection of the best employees every year and the release of an employee who enters full duty, and (3) the opportunity to participate in activities held at the Ministry PANRB include training and reform of internal corner. Second, related infrastructure, improving sanitation and comfort facilities (toilets, clinic, cafeteria, parking area, breastfeeding room and smoking room). Third, an increase in the role of a role model, an agent of change and the integrity of the group to continue to be a driver of change in order to reform the bureaucracy.

\section{Closing}

Theoretically relationship of bureaucratic reform and organizational culture in essence can be expressed as follows: First, the culture of the organization that supported the leadership commitment to positively affect the performance of the apparatus; Second, the success of the reform of the bureaucracy can be viewed as a cultural, structural, process; Third, the model of bureaucratic reform in Indonesia, including the open model; Fourth, bureaucratic reform is realized with the ability to innovate to improve public service delivery; Fifth, the purpose and manner of bureaucratic reforms, namely the existence of an efficient public administration, serving, decentralization, transparency and participation; Sixth, leadership style has no direct influence on the performance of the organization, but it can affect organizational performance indirectly through the culture of the organization; Seventh, the evaluation of organizational culture can be used as a tool to map the position of the organization by comparing the objectives, strategies and expected results; and Eighth, there are four models of organizational culture that is associated with adaptation, mission, consistency, and involvement in promoting the growth of the organization as well as cultural models built has two properties that is strong (strong), dynamic and adaptive.

In connection with the empirical problem of the bureaucracy reform the organizational culture, it can be concluded that the reform of the bureaucracy and organizational culture is closely related, but there are various opinions that successful implementation of bureaucratic reforms, among others: (1) leadership commitment; (2) The success of the bureaucracy reform can be viewed as a cultural, structural, process; (3) the existence of a model of open or closed reform; (4) the ability to innovate to improve public services; (5) the purpose and manner of bureaucratic reforms creation of efficient public administration, serving, decentralization, transparency, participation, and development of employee morality; (6) organizational culture can be used as a tool to map the position of the organization; and (7) there are four models of organizational culture to improve organizational performance is an adaptation, mission, consistency, coupled with its involvement is strong, dynamic and adaptive.

Organizational culture is associated with the bureaucracy reform, both emperical and teoritical problems, there are differences and similarities as such, but there is a key factor for the implementation of bureaucratic reforms succeed: first, political commitment and leadership; second, a coalition of stakeholders and co-partnership; Third, clarity trajectory change; Fourth, reform of the modifiers (reform the Reformers); Fifth, a comprehensive roadmap and implementation stages.

Thus a strong organizational culture will affect all members of the organization to work motivated and behave shown to the satisfaction of working to produce daily performance in order to achieve organizational goals have been set as the meaning and significance of bureaucratic reform.

Further research can be done on the public bureaucracy but on a larger scale in order to determine how the relationship of organizational culture will affect motivation, job satisfaction and employee performance. 


\section{Acknowledgements}

I said thanks to Prof. Eko Prasojo (Vice Minister of PANRB) and Didid Noordiatmoko, Ak, MM (Secretary of Internal Bureaucracy Reform Team of The Ministry of PANRB) who have helped and supported the writing of this article.

\section{References}

Albrow, M. (1996). Birokrasi, Terjemahan M. Rusli Karim. Tiara Wacana, Yogyakarta.

Blau, P. M., \& dan Meyer, M. W. (2000). Birokrasi Dalam Masyarakat Modern (translated version). Prestasi Pustaka Karya, Jakarta.

Caiden, G. E. (1991). Adminisrative Reform Comes of Age. Walter de Gruyter, Berlin, New York.

Effendi, S. (2012). Reformasi Tata Kepemerintahan, Menyiapkan Aparatur Negara Untuk Mendukung Demokratisasi Politik dan Ekonomi Terbuka. Gadjah Mada University Press, Yogyakarta.

Effendi, T. (2010). ABC Reformasi Birokrasi, Biro Hukum dan Humas Kementerian Pendayagunaan Aparatur Negara dan Reformasi Birokrasi, Jakarta.

Keban, Y. T. (2008). Enam Dimensi Strategis Administrsai Publik Konsep, Teori dan Isu, Gava Media, Yogyakarta.

Keban, Y. T. (2010). Isu Pengembangan Kapasitas dan Good Governance dalam Reformasi Birokrasi, dalam Buku Reformasi Aparatur Negara Ditinjau Kembali, Yogyakarta, Gaya Media.

Kementerian Pendayagunaan Aparatur Negara dan Reformasi Birokrasi (Kementerian PANRB). (2012). Bunga Rampai Bahan Penyusunan Kebijakan, Jakarta.

Koesmono, Pengaruh Budaya Terhadap Motivasi dan Kepuasan Kerja serta Kinerja Karyawan pada Sub Sektor Industri pengolahan Kayu Skala Menengah di Jawa Timur.

Maskun, I. R. (2013). Reformasi Birokrasi, Terobosan dan Tantangan MenPANRB, Jakarta.

Prasojo, E. (2013). Pemimpin dan Reformasi Birokrasi, Catatan Inspiratif dan Alat Ukur Kepemimpinan dalam Implementasi Reformasi Birokrasi, Kementerian PANRB dan giz, Jakarta.

Prasojo, E. (2014). Reformasi Birokrasi Untuk Mewujudkan Tata Pemerintahan Demokratis Dan Pembangunan Berkeadilan (bahan paparan), Jakarta.

Rewansyah, A. (2010). Reformasi Birokrasi Dalam Rangka Good Governance, Yusaintanas Prima, Jakarta.

Sailiwa Wirman Syafri, Peningkatan Kinerja Aparatur Negara Melalui Penataan Sistem Manajemen Pegawai Negeri Sipil Dalam Rangka Peningkatan Daya Saing Nasional, Jurnal Pendayagunaan Aparatur Negara Edisi II Tahun II 2012.

Sembiring Masana, Budaya dan Kenerja Organisasi (Perspektif Organisasi Pemerintah), Bandung, Fokusmedia, 2012.

Setiyono, B. (2012). Birokrasi Dalam Perspektif Politik dan Administrasi, Nuansa, Bandung.

Siagian, S. P. (1996). Patologi Birokrasi, Bumi Aksara.

\section{Copyrights}

Copyright for this article is retained by the author(s), with first publication rights granted to the journal.

This is an open-access article distributed under the terms and conditions of the Creative Commons Attribution license (http://creativecommons.org/licenses/by/3.0/). 